\title{
Creación del Instituto de Investigaciones Arqueológicas R. P. Gustavo Le Paige s. j. Universidad del Norte, San Pedro de Atacama
}

\section{Su creación}

De acuerdo al decreto de Rectoría No 966 del año 1984 de la Universidad del Norte se integró el Departamento de Arqueología de su sede de Antofagasta al Museo Arqueológico de San Pedro de Atacama, fundado por el R. P. Gustavo Le Paige s. j. (1980†) en el principal oasis atacameño de los Andes de la II Región de Chile.

Esta nueva unidad científica depende de la Dirección General de investigaciones, extensión y asistencia técnica, y centraliza su labor mediante un programa que identifica, analiza, sistematiza y divulga materias concernientes al patrimonio antropológico, arqueológico y ecológico de las poblaciones prehistóricas y su supervivencia contemporánea, en el contexto del Area Centro Sur andina. Su vocación de reflexión, investigación y servicio, en el propio mundo andino, ha ratificado el impacto nacional e internacional que ha suscitado el foco cultural de San Pedro de Atacama.

\section{Los objetivos}

El Instituto valoriza la herencia cultural del padre Le Paige y contribuye a jerarquizar a nivel universitario las actuales labores de investigación, docencia y extensión en el territorio atacameño.

Para este efecto investiga, conserva y concentra el patrimonio antropológico-arqueológico al servicio de la comunidad científica y estudiosos en general, enfatizando una mejor comprensión por las culturas vernáculas del pasado y presente de su entorno andino.

\section{Su funcionamiento}

Se localiza en el pueblo de San Pedro de Atacama a $2360 \mathrm{~m} . \mathrm{snm}$ entre notables tradiciones indígenas e hispanas, distante a $100 \mathrm{~km}$ de Calama y 370 $\mathrm{km}$ de Antofagasta, las ciudades más próximas (Figura 1).

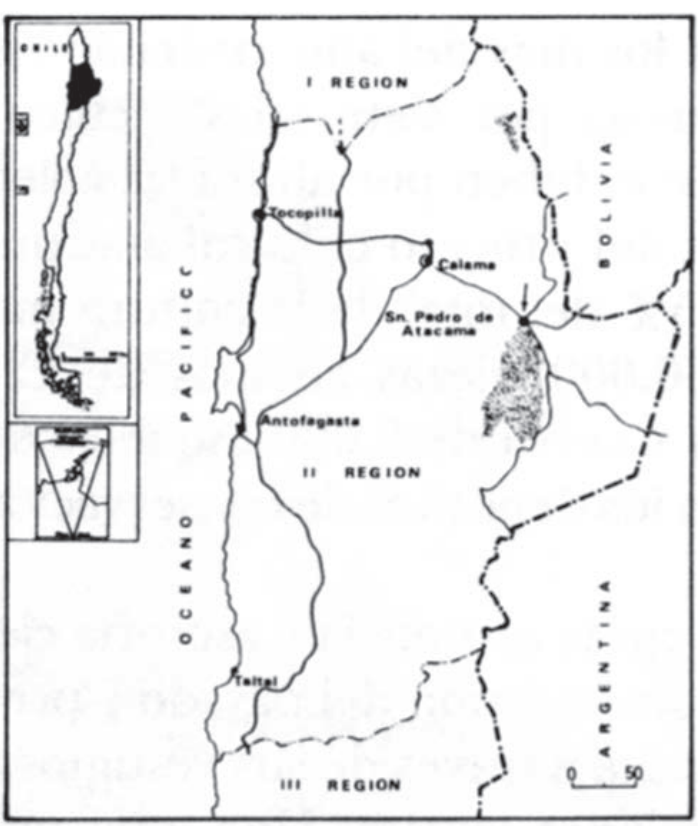

Figura 1. Ubicación de San Pedro de Atacama en la II Región.

Un edificio de arquitectura típica $\left(3000 \mathrm{~m}^{2}\right)$ alberga tres grandes rotondas destinadas una a Exposición permanente donde se aprecia un montaje didáctico sobre la evolución de las culturas atacameñas, otra a la investigación con cinco oficinas-laboratorios y sala de Conferencia, y una última rotonda en actual proceso de puesta en valor museográfico.

Complementan las dependencias una sala de exposición temporal, depósitos, sala de ventas, redacción de la revista Estudios Atacameños, sala de homenaje al R. P. Gustavo Le Paige, oficina de Dirección y una biblioteca especializada con servicio de rastreo de información.

\section{La estructura académica}

El Instituto se conduce a través de un programa de renovación quinquenal, apoyado por las Divisiones de Arqueología-Antropología Física, MuseografíaConservación y Documentación. 
Un equipo compuesto por un Director académico, cuatro académicos (doctores, licenciados y titulados), un asistente de administración, secretariado y asistente de biblioteca, más cinco técnicos especializados, está dedicado a la valoración del patrimonio, conjuntamente con proyectos de investigación y extensión, al tanto que prepara un programa de capacitación profesional en arqueología interandina, a nivel de postgrado. Este programa se apoya en el acceso múltiple hacia este enclave fronterizo, las necesidades comunes de perfeccionamiento en el área y el potencial de recursos arqueológicos diversificados.

\section{El Museo Arqueológico}

La extensión del Instituto se refleja en su museo (Figura 2), abierto todos los días del año, ordenado en una rotonda compuesta por siete salas y cinco depósitos $\left(1038 \mathrm{~m}^{2}\right)$. Se exhiben por ahora las colecciones representativas del proceso cultural atacameño, equivalentes al $15 \%$ del total de la cultura material que alcanza a 380000 piezas además de 229 cuerpos momificados y cerca de 5000 esqueletos humanos, dispuestos en los depósitos de conservación e investigación.

Se proporciona asistencia y asesoría científica para la mejor comprensión del pasado y presente de la etnia atacameña, a través de sus vestigios antropológicos y tradiciones locales. Una guía publicada en español e inglés ayuda a tales propósitos.

\section{Convenios con instituciones e investigadores nacionales y extranjeros}

Con el objeto de colaborar con científicos visitantes y perfeccionar su propio Programa, el Instituto establece convenios de mutuo beneficio en los siguientes casos:

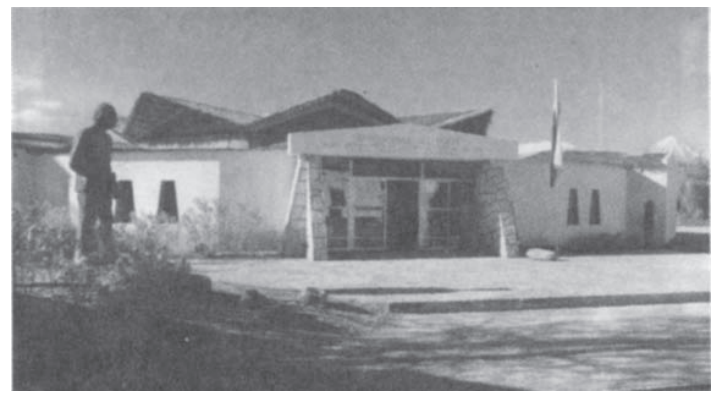

Figura 2. Museo Arqueológico de San Pedro de Atacama.

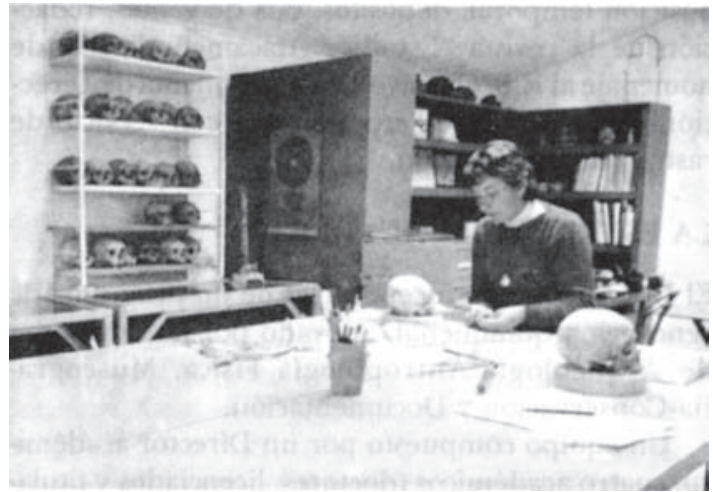

- Recepción de profesores visitantes e investigadores.

- Recepción de tesistas de pregrado, máster y doctorado.

- Recepción de misiones y labores conjuntas en el contexto de las Divisiones del Instituto.

- Recepción de voluntarios para salvamento de bienes culturales.

- Asesoría de cine documental y educativo.

- Convenios para implementar la creación de la Escuela Interandina de Arqueología de Postgrado (Proyecto).

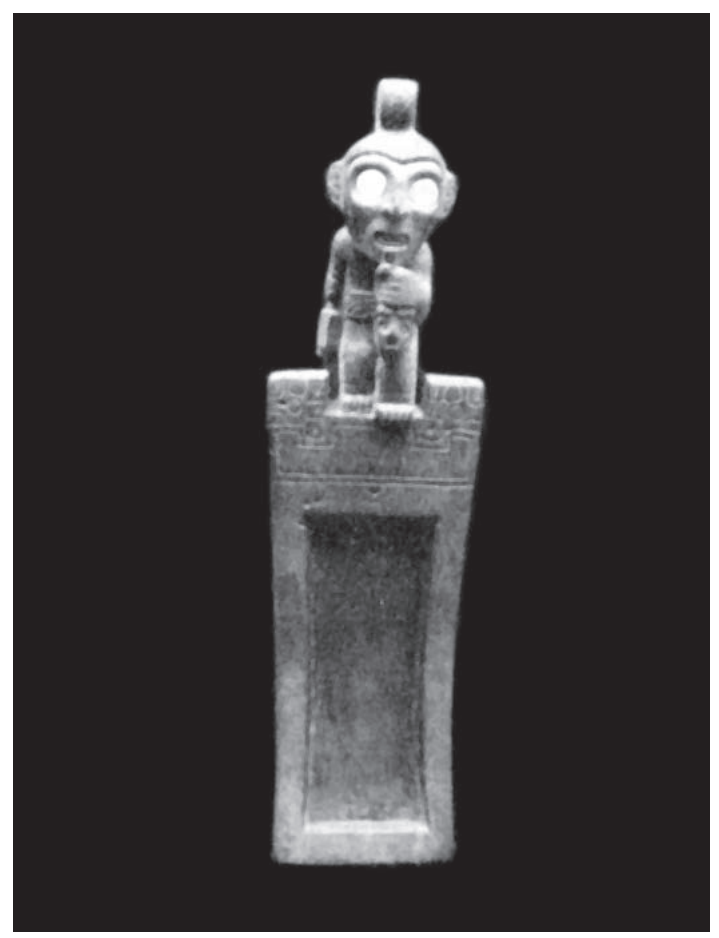


- Organización y asesoría de viajes de estudio y circuitos de turismo cultural.

- Organización de cursos o ciclos de capacitación cultural a nivel local, regional y nacional.

- Elaboración de proyectos destinados a salvaguardar el patrimonio arqueológico y sobrevivencia atacameña contemporánea, a través de donaciones para fines culturales deducidos de impuestos.
Enviar proyectos y propuestas o solicitar información adicional en la siguiente dirección:

Instituto de Investigaciones Arqueológicas Universidad del Norte (fono 2)

San Pedro de Atacama (II Región), Chile.

"San Pedro de Atacama, capital arqueológica de Chile: Salvemos ahora su pasado y su presente". 


\section{The creation of the Rev. Gustavo Le Paige, s. j. Institute of Archaeological Research Universidad del Norte, San Pedro de Atacama}

\section{Its creation}

According to Decree No 966 , issued by the Rector of the University of the North in 1984, the Archaeological Museum of San Pedro de Atacama was incorporated into the Department of Archaeology from its Antofagasta seat. The museum was founded by the Rev. Gustavo Le Paige s.j. (died 1980) in the main oasis of the Atacama Desert in the Andes of the $2^{\text {nd }}$ Region of Chile.

This new scientific unit is subject to the General Administration of Research, External Activities and Technical Assistance. It concentrates its work through a programme which identifies, analyzes, classifies and disseminates themes concerning the anthropological, archaeological and ecological heritage of the prehispanic peoples and its contemporary survival in the area of the South Central Andes.

Its dedication to academic thought, research and usefulness in the Andean world itself, has confirmed the national and international impact which this, the cultural focus of San Pedro de Atacama, has aroused.

\section{The aims}

The Institute values the cultural inheritance of Father Le Paige and helps organize at university level the work being currently undertaken of research, teaching

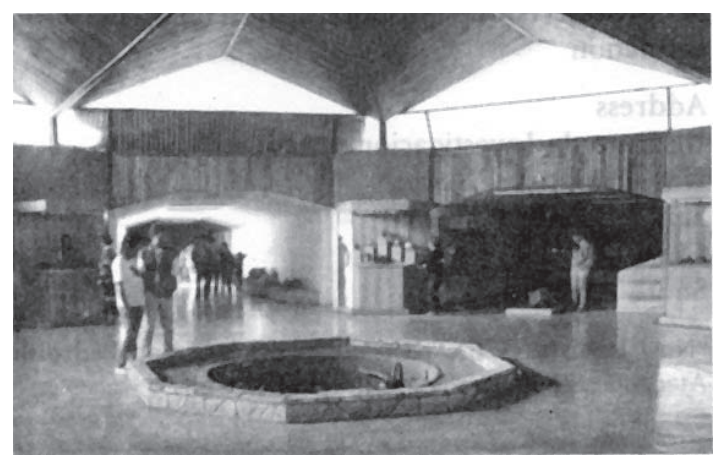

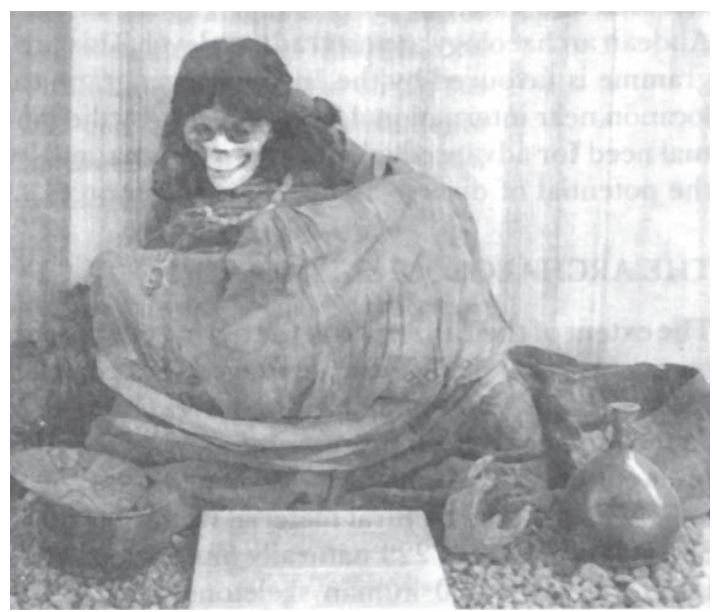

and external activities in the Atacama area. In order to do this, it conducts research, curates and directs its attention towards the anthropological and archaeological heritage, making it available to the scientific community and to students in general, emphasising a better understanding for the vernacular cultures of the past and present in their Andean context.

\section{How it works}

It is located in the town of San Pedro de Atacama at $2360 \mathrm{~m}$.asl, $100 \mathrm{~km}$ from Calama and $370 \mathrm{~km}$ from Antofagasta. The town is noted for its indigenous and hispanic traditions.

A building of typical architecture $\left(3000 \mathrm{~m}^{2}\right)$ houses three large rotundas, one of which is designed to display a permanent exhibition, a didactic presentation of the evolution of the Atacama cultures, another is dedicated to research, with five office-laboratories and a conference room. The last rotunda is at the moment being arranged as museum space.

Smaller spaces complement the rotunda; a temporary exhibition room, stores, a sales room, with the edition of the publication Estudios Atacameños, a room in hommage to Rev. Gustavo Le Paige, Director's office and a specialized library with an information search service. 


\section{The academic structure}

The Institute is administered by a Directorate, through a programme of five yearly renewal, supported by the Divisions of Archaeology-Physical Anthropology, Muscology-Conservation and Documentation.

A team composing of a Director academic, four academics (doctorates, licenciados and titulados), an administrative assistant, a secretary and an assistant librarian, plus five especialized technicians, is dedicated to the appreciation of the heritage, along with research and external professional training in inter Andean archaeology at postgraduate level. This programme is favoured by the Institute's geographical location near international frontiers, also by the mutual need for advanced education in the area, and by the potential of diverse archaeological resources.

\section{The Archaeological Museum}

The extent of the Institute is reflected in its Museum, open every day of the year, arranged in a rotunda composed of seven rooms and five stores $\left(1038 \mathrm{~m}^{2}\right)$. At the moment collections representative of the Atacama cultural development are exhibited, equivalent to $15 \%$ of the total cultural material which has up to 380.000 pieces, plus 229 naturally mummified bodies and about 5000 human skeletons, kept in the conservation and research stores.

Scientific assistance and consultation provide for a better understanding of the past and present of the Atacama people, through their anthropological remains and local traditions. A guide published in Spanish and English helps such aims.

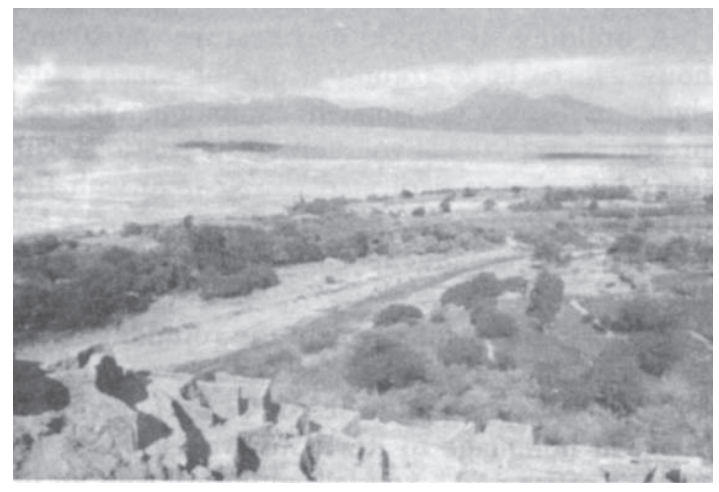

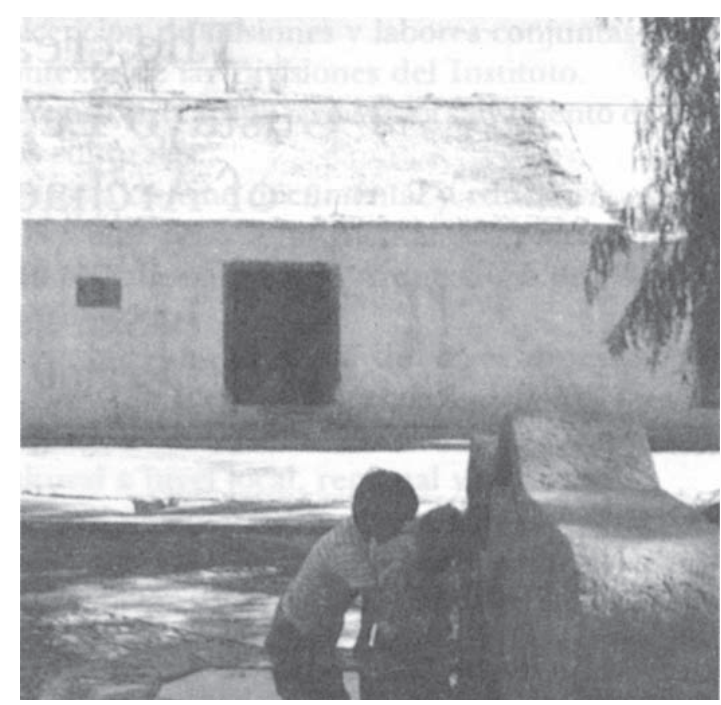

\section{Conventions with institutions and national and foreign researchers}

With the aim of collaborating with visiting scientists and to perfect its own Programme, the Institute establishes conventions of mutual benefit in the following cases:

- The reception of visiting teachers and researchers.

- The reception of persons working on undergraduate, masters and doctoral theses.

- The reception of teams and programmes of work in conjunction with the Divisions of the Institute.

- The reception of volunteer helpers to safeguard the cultural heritage.

- Consultation for documentary and educational cinema.

- Conventions to implement the creation of the Inter-Andean Postgraduate School of Archaeology (Project).

- The organization of an advice on study tours and cultural tourist routes.

- The organisation of cultural training courses or series of courses at local, regional and national level. 
- The development of projects designed to safeguard the archaeological heritage and contemporary survivals through donations for cultural ends, deducted from taxes.

Send projects and proposals, or request more information to the following address:
Instituto de Investigaciones Arqueológicas, Universidad del Norte,

San Pedro de Atacama, Chile.

"Now let us save the past and present of San Pedro de Atacama, the archaeological capital of Chile". 